\title{
Relative Differences in Yield for Strawberry (Fragaria xananassa Duch.) Genotypes Are Stable over Differing Levels of Infestation by Twospotted Spidermites (Tetranychus urticae Koch.)
}

\author{
Douglas V. Shaw \\ Department of Pomology, University of California, Davis, CA 95616
}

Frank G. Zalom

Department of Entomology, University of California, Davis, CA 95616

Kirk D. Larson

Department of Pomology, University of California, Davis, CA 95616

AdDitional Index words. Tetranychus urticae, Fragaria, yield, genotypes, host plant resistance

\begin{abstract}
Eighteen strawberry genotypes from the University of California's breeding population were evaluated over two years for yield and fruit size with complete, partial, and no control of natural infestation by Tetranychus urticae Koch. The numbers of mites per leaf accumulated for the entire season or counted at peak infestation, and the number of mite-days accumulated for the season for partial control treatments were $31.7 \%$ to $44.0 \%$ of corresponding values realized for uncontrolled infestation, and values differed significantly between treatments for all three variables. Yields for the no-control and partial-control treatments averaged $81.6 \%$ and $85.0 \%$ of the yields obtained with complete spidermite suppression for the 2 trial years; fruit sizes were $95.1 \%$ and $92.0 \%$ for corresponding comparisons. Yield and fruit size differed significantly between the complete-control treatment and any level of infestation, but statistically significant differences between partial and complete mite control treatments were detected only for fruit size in a single year. Analysis of variance demonstrated significant or highly significant variation due to control level, genotype, and their interactions for both yield and fruit size, but resolution of variance components demonstrated that genetic $\times$ treatment interactions explained just $0 \%$ to $8 \%$ of the phenotypic variance for yield and fruit size in a 2-year evaluation. Genotypic variances, those reflecting genetic effects that were stable across treatments, were at least 9.3 times as large as interaction variances for these traits. There appears to be no evidence for partial resistance that might be expressed at intermediate levels of spidermite infestation.
\end{abstract}

Studies conducted throughout the past several decades have provided conflicting results regarding the opportunity for breeding strawberry (Fragaria $\times$ ananassa Duch.) cultivars resistant to twospotted spidermites (Tetranychus urticae Koch.). Several studies have demonstrated significant genetic variation for traits potentially related to spidermite resistance in domestic strawberry and its wild relatives (Barritt, 1980; Gimenez-Ferrer, 1993; Shanks and Moore, 1995). These studies measured spidermite infestation levels or scored damage variables for different genotypes, rather than evaluating direct effects on productivity. Conversely, research using an extensive sample of germplasm from the University of California's strawberry improvement program (Walsh et al., 2002) demonstrated minimal genotypic $\times$ infestation level interactions for yield, despite the presence of substantial genotypic variation for mite infestation variables. The high stability for productivity detected for these strawberry genotypes across uncontrolled and minimal levels of spidermite infestation in this latter study suggested little opportunity for direct genetic improvement of spidermite resistance that will mitigate yield losses. These contradictory results lead to an important caution in spidermite resistance breeding: although infestation and damage scores can be useful as indirect traits for scoring resistance to spidermites, their utility ultimately depends on the relationship between these indirect traits and productivity or other traits of commercial importance.

The relationship between indirect measures of spidermite resis-

Received for publication 17 Jan. 2003. Accepted for publication 13 May 2003. tance and productivity can be further complicated by differences in infestation rates across environments together with interactions between genotypes and infestation rates. Both absolute and relative rates of infestation can differ substantially for individual strawberry genotypes across locations (Medina et al., 1999), and due to cultural practices (Walsh et al., 1997). The extent to which genotypes respond differently to differing infestation levels is not known, and may comprise a partial explanation for the disparate results obtained through observation of infestation variables and productivity. For example, although the relationships between measures of spidermite infestation and yield reductions for individual genotypes reported by Walsh et al. (2002) were weak $\left(R^{2}=\right.$ $0.22-0.23$ ), all results for infested treatments in these studies were obtained using unconstrained mite populations. Partial resistance that might be expressed at intermediate rates of infestation, and be of substantial practical value, could be overwhelmed by extreme pest levels. Little work is available to indicate the relative stability of strawberry genotypes for yield loss over environments that condition differing infestation levels, and studies reported below were conducted to evaluate this relationship.

\section{Materials and Methods}

Field trials were established in Fall 1998 and 2000 at the University of California Strawberry Research Facility near Watsonville (lat. $3654^{\prime} \mathrm{N}$, long. $12148^{\prime} \mathrm{W}$ ) by transplanting selected bareroot strawberry runner plants that were harvested 
on 15 Oct. of each year from a high-elevation $(1,300 \mathrm{~m})$ strawberry nursery in Macdoel, Calif. (lat. $4145^{\prime} \mathrm{N}$, long. 121 59' W). Eight photoperiodically day-neutral and 10 short-day genotypes with a range of production patterns were tested over these 2 years. Of these genotypes, five were tested in both years. The 18 genotypes were chosen from the current cultivars and advanced selections available from University of California (UC) strawberry improvement program. Eight of the genotypes tested have been released as cultivars before the completion of this study, the remainder were in consideration for release at the time the studies were conducted.

After nursery harvest, short-day and day-neutral genotypes were stored for 1 and 3 weeks, respectively, at $0.5{ }^{\circ} \mathrm{C}$ to increase plant vigor by promoting a chilling response before transplanting into the production plantation (Walsh et al., 1997). Plots were established after preplant soil fumigation using 2 methyl bromide : 1 chloropicrin (wt/wt), at $392 \mathrm{~kg} \cdot \mathrm{ha}^{-1}$. Trials were conducted using two-row diagonal raised beds with 132-cm centers and 34-cm plant spacing along rows (39,540 plants/ha).

Six replications were established in each year, each with a single plot of 20 plants for each genotype. Two replications were treated with acaricides as needed to prevent $T$. urticae infestation, two replicates remained untreated, and the third set of replicates was treated infrequently with acaricides to obtain an intermediate level of spidermite infestation.

Treatments to the intermediate mite level plots were applied with an Echo D9 duster-mister sprayer at a volume of $1875 \mathrm{~L} \cdot \mathrm{ha}^{-1}$ when average mite densities for all genotypes reached 20 per midtier leaflet. In 1999, a single application of abamectin (Agri-mek 0.15EC, Syngenta Crop Protection, Inc., Greensboro, N.C.) was applied at an active ingredient rate of $8.53 \mathrm{~g} \cdot \mathrm{ha}^{-1}$ on 27 May. In 2001, abamectin was applied at an active ingredient rate of 8.53 $\mathrm{g} \cdot \mathrm{ha}^{-1}$ on 31 May. Increasing mite populations necessitated a subsequent application of hexythiazox (Savey, Gowan Co., Yuma, Ariz.) at an active ingredient rate of $21.1 \mathrm{~g} \cdot \mathrm{ha}^{-1}$ tank mixed with etoxizole (Zeal, Valent USA Corp., Walnut Creek, Calif.) at an active ingredient rate of $151.6 \mathrm{~g} \cdot \mathrm{ha}^{-1}$ on $21 \mathrm{June}$.

Tetranychus urticae densities were determined on plants in the untreated and partially treated plots by harvesting 10 mid-tier leaflets per plot every two weeks beginning mid-March in both years, mite brushing and counting the mites present on the leaves (Henderson and McBurnie, 1954). The number of mites per leaflet accumulated over the season (15 Mar. and 30 Aug. 1999 and
2001, respectively) and at the peak of infestation, as well as the seasonal accumulation of mite-days (Andrews and La Pre, 1979) were used as measures for assessing $T$. urticae feeding. Mites were not counted each week on complete acaricide control plots, but periodic monitoring during peak infestation periods indicated that densities never exceeded five mites per leaflet.

Ripe fruit from each plot were harvested weekly from April through August 1999 and 2001, and annual yields were calculated from those harvests as grams of fruit produced per plant. A seasonal measure of fruit size was determined by averaging the weights of 10 randomly chosen fruit per plot on each harvest date.

Measures of mite infestation for partial and no-acaricide treatments were compared using paired $t$ tests. Analyses of Variance (ANOVA) for seasonal yield and fruit size were performed with control level, genotypes, and their interaction as random effects; replications were treated as fixed effects. The number of genotypes common to both trial years was small, thus trials conducted in the two years were analyzed separately using SAS procedure GLM (SAS, 1990) and significance tests were performed using type III expected mean squares. Sources of variation were further resolved by estimation of variance components for all random effects.

The similarity of genotypic responses between the three mite control treatments was further quantified by treating individual traits in different fumigation treatments as separate but genetically correlated, and estimating their genotypic correlation as (Burdon, 1977): $r_{g}=\sigma_{g}^{2} /\left(\sigma_{g}^{2}+\sigma^{2}{ }_{c g}\right)$, where $\sigma_{g}^{2}$ is the estimated genotypic variance and $\sigma_{c g}^{2}$ is the estimated genotypic $\times$ control treatment interaction variance obtained using SAS Procedure Varcomp for pairs of acaricide treatments. This genotypic correlation can be used to predict the correspondence in genetic selection response, where selection is conducted on genotypes tested in one infestation treatment and performance is tested in another.

\section{Results and Discussion}

Seasonal accumulated counts of mites per leaf and mite days differed substantially between the 2 trial years, with values for the 2001 trial $35 \%$ to $58 \%$ larger than for the 1999 trial (Table 1); these between-year differences were statistically significant only for uncontrolled mite infestation treatments $(t=2.50,2.37, d f=$ $24, P<0.02)$. Very little difference was detected in peak infestation mite counts, indicating that yearly differences here likely reflect the duration rather than the maximum intensity of mite feeding.

Table 1. Means ${ }^{\mathrm{z}}$ and SD values (in parentheses) for yield, fruit size, and three measures of two-spotted spidermite infestation for strawberry trials conducted in 1999 and 2001.

\begin{tabular}{|c|c|c|c|c|c|c|}
\hline \multirow[b]{2}{*}{$\begin{array}{l}\text { Trial } \\
\text { year }\end{array}$} & \multirow[b]{2}{*}{$\begin{array}{l}\text { Control } \\
\text { level }\end{array}$} & \multirow[b]{2}{*}{$\begin{array}{c}\text { Yiel } \\
\text { (g/plant) }\end{array}$} & \multirow[b]{2}{*}{$\begin{array}{c}\text { Fruit size } \\
\text { (g/fruit) }\end{array}$} & \multicolumn{3}{|c|}{ Mites/leaf } \\
\hline & & & & Seasonal & Peak & $\begin{array}{l}\text { Seasonal } \\
\text { mite-days }\end{array}$ \\
\hline \multirow[t]{4}{*}{1999} & None & 1337 & 29.7 & 194.8 & 108.6 & 2656 \\
\hline & Partial & 1406 & 28.8 & 75.2 & 40.2 & 982 \\
\hline & & (365) & (3.8) & $(84.0)$ & (49.6) & (1155) \\
\hline & Complete & 1564 & 31.3 & --- & --- & --- \\
\hline \multirow[t]{6}{*}{2001} & None & 1525 & 29.0 & 307.2 & 101.3 & 4180 \\
\hline & & (336) & (3.1) & (178.7) & $(60.6)$ & (2519) \\
\hline & Partial & 1574 & 28.7 & 108.7 & 44.6 & 1324 \\
\hline & & (321) & (3.1) & (90.6) & $(34.2)$ & (1225) \\
\hline & Complete & 1964 & 30.4 & --- & --- & --- \\
\hline & & (330) & (3.2) & & & \\
\hline
\end{tabular}

${ }^{{ }^{2} \mathrm{~N}}=24$ for all means presented here. 
Table 2. Results for analysis of variance for yield and fruit size with three control levels in strawberry trials conducted in 1999 and 2001.

\begin{tabular}{|c|c|c|c|c|c|c|}
\hline \multirow[b]{2}{*}{$\begin{array}{l}\text { Trial } \\
\text { year }\end{array}$} & \multirow[b]{2}{*}{ Source } & \multirow[b]{2}{*}{ df } & \multicolumn{2}{|c|}{ Yield } & \multicolumn{2}{|c|}{ Fruit size } \\
\hline & & & $\begin{array}{l}\text { Mean } \\
\text { square }\end{array}$ & $\sigma^{2}(\%)^{\mathrm{z}}$ & $\begin{array}{l}\text { Mean } \\
\text { square }\end{array}$ & $\sigma^{2}(\%)$ \\
\hline \multirow[t]{4}{*}{1999} & Replication & 1 & $241,513^{* *}$ & --- & 0.2 & --- \\
\hline & Genotype (G) & 11 & $610,454^{* *}$ & 96,385 (74) & $74.4^{* *}$ & $11.83(76)$ \\
\hline & $\mathrm{C} \times \mathrm{G}$ & 22 & $32,146^{* *}$ & $10,832(8)$ & $3.4^{* *}$ & $1.21(8)$ \\
\hline & Error & 35 & 10,483 & $10,483(8)$ & 1.0 & $1.0(7)$ \\
\hline \multirow{4}{*}{2001} & Control level (C) & 2 & $1,386,910^{* *}$ & $56,725(31)$ & $18.9^{* *}$ & $0.74(6)$ \\
\hline & Genotype (G) & 11 & $590,880^{* *}$ & $94,228(56)$ & $55.3^{* *}$ & $9.01(82)$ \\
\hline & $\mathrm{C} \times \mathrm{G}$ & 22 & $25,511^{*}$ & $7,026(4)$ & 1.2 & $0(0)$ \\
\hline & Error & 35 & 11,459 & $11,459(7)$ & 1.3 & $1.3(12)$ \\
\hline
\end{tabular}

zComponent of variance attributable to each source and percentage of the phenotypic variance in parentheses.

${ }^{*}, * *$ Statistical significance at $P=0.05$ or 0.01 , respectively.

Table 3. Genotypic correlations $\left(\mathrm{r}_{\mathrm{G}}\right.$ ) for yield and fruit size with three levels of spidermite control in strawberry trials conducted and pooled over 2 years.

\begin{tabular}{lccccc}
\hline Control & \multicolumn{2}{c}{$\mathrm{r}_{\mathrm{G}}$ for yield } & & \multicolumn{2}{c}{$\mathrm{r}_{\mathrm{G}}$ for fruit size } \\
\cline { 2 - 3 } \cline { 5 - 6 } level & Partial & Complete & & Partial & Complete \\
\hline None & $0.98^{* *}$ & $0.84^{* *}$ & & $0.98^{* *}$ & $0.89^{* * *}$ \\
Partial & ---- & $0.91^{* *}$ & & ---- & $0.97^{* *}$ \\
\hline
\end{tabular}

*Statistical significance at the $P=0.01$.

Despite the absolute differences detected for mites per leaf and mite days between years, the relative rates of infestation between partial control and no-control treatments were rather consistent. Counts of mites per leaf accumulated for the total season or at peak infestation, and the number of mite-days accumulated for the season for partial control treatments were $31.7 \%$ to $44.0 \%$ of corresponding values realized for uncontrolled infestation (Table 1). Differences between partial and no-acaricide treatments were highly significant $(P<0.01)$ for all three variables in both years $(t=3.47-5.00, d f=46)$.

Highly significant variances due to spidermite control level and genotype were detected for yield and fruit size in both years (Table 2). The significant variances for control level reflect substantial differences in trait means between infestation treatments: the no-acaricide and partial acaricide treatments averaged $81.6 \%$ and $85.0 \%$ of the yields obtained with complete spidermite suppression over both years; fruit sizes were $95.1 \%$ and $92.0 \%$ for corresponding comparisons (Table 1). Posthoc pairwise com- parisons using Bonferonni's $t$ test detected significant $(P<0.05)$ differences for both yield and fruit size between either partial or no-acaricide treatments and complete control, but a statistically significant difference was detected between partial and complete control only for fruit size in the 1999 trial. Despite substantial and significant differences for indicators of mite feeding between partial and no-acaricide treatments, reductions in yield and fruit size were similar for both infestation treatments. Genotypic variances explained $56 \%$ to $82 \%$ of the phenotypic variance in this trial (Table 2). Differences among genotypes for yield and fruit size were the major contributor to the phenotypic variance in all cases, ranging from 1.8 to 13.7 times as large as the component of variance introduced due to variable rates of infestation.

Variances due to genotype $\times$ control level interaction were significant or highly significant for yield in both years and for fruit size in the 1999 trial, but explained a maximum of $8 \%$ of the phenotypic variance (Table 2). Genotypic variances, those reflecting genetic effects that were stable across all three acaricide treatments, were at least 9.3 times the magnitude of corresponding interaction variances for these traits. Furthermore, genotypic correlations for yield and fruit size treated as separate traits in the three infestation environments were uniformly large $\left(\mathrm{r}_{\mathrm{G}}=\right.$ 0.84-0.98; Table 3). Although the correlations were slightly larger for partial and complete control environments $\left(\mathrm{r}_{\mathrm{G}}=0.91\right.$ and 0.97 for yield and fruit size, respectively) than for no-control and complete control environments $\left(\mathrm{r}_{\mathrm{G}}=0.84\right.$ and 0.89 for yield and fruit size, respectively), these differences were not statisti-

Table 4. Results for analysis of variance for three measures of two-spotted spidermite infestation with two control levels in strawberry trials conducted in 1999 and 2001.

\begin{tabular}{|c|c|c|c|c|c|c|c|c|}
\hline \multirow[b]{2}{*}{$\begin{array}{l}\text { Trial } \\
\text { year }\end{array}$} & \multirow[b]{2}{*}{ Source } & \multirow[b]{2}{*}{ df } & \multicolumn{2}{|c|}{ Seasonal mites/leaf } & \multicolumn{2}{|c|}{ Peak mites/leaf } & \multicolumn{2}{|c|}{ Seasonal mite days } \\
\hline & & & $\begin{array}{l}\text { Mean } \\
\text { square }\end{array}$ & $\sigma^{2}(\%)^{z}$ & $\begin{array}{l}\text { Mean } \\
\text { square }\end{array}$ & $\sigma^{2}(\%)$ & $\begin{array}{l}\text { Mean } \\
\text { square }\end{array}$ & $\sigma^{2}(\%)$ \\
\hline \multirow[t]{4}{*}{1999} & Replication & 1 & $2.51^{*}$ & --- & $1.50^{*}$ & --- & 1.88 & ---- \\
\hline & Genotype $(\mathrm{G})$ & 11 & $1.91^{* *}$ & $0.40(27)$ & $2.28^{* *}$ & $0.50(29)$ & $2.13^{* *}$ & $0.46(28)$ \\
\hline & $\mathrm{C} \times \mathrm{G}$ & 11 & 0.30 & $0.00(0)$ & 0.28 & $0.00(0)$ & 0.31 & $0.00(0)$ \\
\hline & Error & 23 & 0.41 & $0.41(28)$ & 0.56 & $0.56(32)$ & 0.49 & $0.49(27)$ \\
\hline \multirow{4}{*}{2001} & Control level (C) & 1 & $18.54^{* *}$ & $0.76(64)$ & $11.05^{* *}$ & $0.44(51)$ & $24.22^{* *}$ & $0.99(64)$ \\
\hline & Genotype (G) & 11 & 0.71 & $0.05(5)$ & 0.67 & $0.04(5)$ & 0.74 & $0.10(7)$ \\
\hline & $\mathrm{C} \times \mathrm{G}$ & 11 & 0.50 & $0.13(11)$ & 0.52 & $0.14(16)$ & 0.54 & $0.12(8)$ \\
\hline & Error & 23 & 0.25 & $0.25(21)$ & 0.24 & $0.24(28)$ & 0.30 & $0.30(21)$ \\
\hline
\end{tabular}

${ }^{\mathrm{z} C o m p o n e n t ~ o f ~ v a r i a n c e ~ a t t r i b u t a b l e ~ t o ~ e a c h ~ s o u r c e ~ a n d ~ p e r c e n t a g e ~ o f ~ t h e ~ p h e n o t y p i c ~ v a r i a n c e ~ i n ~ p a r e n t h e s e s . ~}$

**** Statistical significance at $P=0.05$ or 0.01 , respectively. 
cally significant. Performance for either trait is thus expected to be similar regardless of the infestation environment in which the genotypes are selected or eventually grown. Importantly, the genes that determine variation for yield were expressed consistently across a range of infestation levels, and there appears to be no evidence for partial resistance that might be expressed at intermediate levels of spidermite infestation.

A possible explanation for the absence of genotype $\times$ infestation level interactions in this set of genotypes is that they all permit uniformly high infestation rates. This germplasm might thus express only genetic variation for tolerance to high infestation and lack genetic mechanisms that limit infestation and confer true resistance. Further resolution of the three measures of two-spotted spidermite infestation by ANOVA suggest that this explanation is unlikely. ANOVA results demonstrated highly significant genotypic variation for these traits for the 1999 trial $\left(\sigma^{2}{ }_{g}=27 \%\right.$ to $29 \%$ of the phenotypic variance) but virtually none for the 2001 trial $\left(\sigma_{\mathrm{g}}^{2}=4 \%\right.$ to $7 \%$ of the phenotypic variance) (Table 4$)$. However, no substantial difference for the fraction variance of either yield or fruit size explained by genetic $\times$ infestation level interaction was detected between these trials (Table 3); together, these results demonstrate an absence of correspondence between genetic mechanisms that control infestation and their eventual consequences for yield or fruit size. The latter conclusion is consistent with prior observations that measures of spider mite infestation for individual genotypes are rather poor predictors of yield reduction at high infestation rates (Walsh et al., 2002). The observation that rather low levels of mite infestation can cause substantial yield reduction (Walsh et al., 1998) together with our current results suggest that breeding for genetic resistance mechanisms that reduce infestation is likely to be an effective strategy only if the exclusion of spidermites is rather complete.

\section{Literature Cited}

Andrews, K.L. and LLaPre. 1979. Effect of Pacific mite on physiological processes of almond foliage. J. Econ. Entomol. 72:651-654.

Barritt, B.H. 1980. Breeding for resistance to insects and mites, p. 201-213. In: N.F. Childers (ed.). The strawberry, cultivars to marketing. Horticultural Publications, Gainesville, Fla.

Burdon, R.D. 1977. Genetic correlation as a concept for studying genotype $\times$ environment interaction in forest tree breeding. Silvae Genet. 26:168-175.

Gimenez-Ferrer, R.M.G., J.C. Scheerens, and W.A. Erb. 1993. In vitro screening of 76 strawberry cultivars for two-spotted spider mite resistance. HortScience 28:841-844.

Henderson, C.F. and H.V. McBurnie. 1954. Sampling techniques for determining populations of citrus red mite and its predators. USDA Circ. 671.

Medina, J.L., P.P. Moore, C.H. Shanks, Jr., F.F. Gil, and C.K. Chandler. 1999.Genotype $\times$ environment interaction for resistance to sidermites in Fragaria. J. Amer. Soc. Hort. Sci. 124:353-357.

SAS Institute. 1990. SAS/STAT user's guide. release 6.04. SAS Inst., Cary, N.C.

Shanks, C.H. and P.P. Moore. 1995. Resistance to two-spotted spider mite and strawberry aphid in Fragaria chiloensis, F. Virginiana, and F. xananassa clones. HortScience 30:596-599.

Walsh, D.B., F.G.Zalom, N.C. Welch, and D.V. Shaw. 1997. Preplant cold storage of strawberries: Effects on plant vigor, yield, and spider mite (Acari: Tetranychidae) abundance. J. Econ Entomol. 90:818-823.

Walsh, D.W, F.G. Zalom, and D.V. Shaw. 1998. Interaction of the twospotted spidermite (Acari: Tetranychidae) with yield of day-neutral strawberries in California. J. Econ. Entom. 91:1-8.

Walsh, D.B., F.G. Zalom, D.V. Shaw, and K.D. Larson. 2002. Yield reduction caused by twospotted spidermite (Acari:Tetranychidae) feeding in an advanced cycle strawberry breeding population. J. Amer. Soc. Hort. Sci. 127:230-237. 